\title{
NATURAL INFECTIONS OF SIMULIUM BIDENTATUM (DIPTERA: SIMULIIDAE) WITH LARVAE OF ONCHOCERCA SPP., IN RELATION TO A HUMAN ZOONOTIC ONCHOCERCIASIS IN OITA, JAPAN
}

\author{
Hiroyuki TakaOKA ${ }^{1}$, Minoru Baba ${ }^{1}$ ANd Odile Bain ${ }^{2}$ \\ Received June 7 1989/Accepted August 301989
}

\begin{abstract}
A total of 579 wild female flies belonging to eight species of Simulium were collected on human baits, in relation to the transmission of a human zoonotic onchocerciasis found in Oita, Japan. Simulium bidentatum was the most dominant species. Natural infections with filarial larvae were found in 11 of 449 S. bidentatum (or $6.5 \%$ of the parous flies) and in 1 of $23 \mathrm{~S}$. aokii (or $10 \%$ of the parous flies). All the infected flies had 1-4 either first-, second- or early third-stage larvae in the thorax. Examination of third-stage larvae shows that $S$. bidentatum is infected with at least two species of Onchocerca. Our result represents the first record of natural Onchocerca infections in Japanese Simuliidae, and also suggests the possibility of S. bidentatum as the potential vector of zoonotic Onchocerca spp. to humans.
\end{abstract}

\section{INTRODUCTION}

Four human cases of zoonotic onchocerciasis have been reported from various areas of the world (Azarova et al., 1965; Siegenthaler and Gubler, 1965; Beaver et al., 1974; Ali-Khan, 1977). An additional case was recently found in Oita, southern Japan (Hashimoto et al., 1990). Examination of histological sections of a female nematode found suggested that, as in all the previous cases, its morphological features resemble those of Onchocerca gutturosa Neumann, 1910 and O. cervicalis Railliet et Henry, 1910 infecting cattle and horses respectively (Beaver et al., 1989).

Several Onchocerca spp. including O. gutturosa and $O$. cervicalis have been reported from Japan (Sato et al., 1954; Suzuki et al., 1982). However, no transmission studies of these filarial nematodes have been carried out, although biting midges (Culicoides spp.) or blackflies (Simulium spp.) have been known as the vectors of certain Onchocerca spp. elsewhere (Bain and Chabaud, 1986).

1 Division of Medical Zoology, Medical College of Oita, Hazama, Oita 879-56, Japan

2 Laboratoire Des Zoologie Vers. Museum National d'Histoire Naturelle, 61, Rue de Buffon, 75231 Paris Cedex 05, France

This study was supported by a Grant-in-Aid for Scientific Research from the Ministry of Education, Science and Culture of Japan (No. 01570216) 
The objective of this study is to investigate the transmission of zoonotic onchocerciasis which may be acquired by humans. In this paper, we report natural Onchocerca infections of S. bidentatum Shiraki collected in one of the suburban residential areas of the city of Oita, where a human zoonotic onchocerciasis occurred.

\section{MAterials AND MethodS}

The patient infected with a zoonotic Onchocerca, a two-year-old Japanese girl, was an inhabitant of Tabaru, one of the suburban residential areas (altitude ca. $30 \mathrm{~m}$ above sea level; coordinates $131^{\circ} 35^{\prime} \mathrm{E} ; 33^{\circ} 10^{\prime} \mathrm{N}$ ), situated in the western part of the city of Oita. It was presumed that the zoonotic Onchocerca infection might have been acquired by this child at or near her residential area, because, living in one of the housing complexes (ca. $0.01 \mathrm{~km}^{2}$ ), she used to spend her time with her mother during the daytime at the recreation ground (ca. $1,200 \mathrm{~m}^{2}$ ) located on the west within their premises, and had never left the city, according to her mother. It was therefore attempted to collect biting midges or blackflies at the corner of this recreation ground. Adjacent to this place on the west lies another huge housing area recently developed (with an extension of about $0.4 \mathrm{~km}^{2}$ ). There is a low hill with a shrubbery just behind these living areas on the south. On the north, a flat farmland mainly used for rice cultivation widely opens and in its center the Oita River runs eastwards which is, at the nearest, about $400 \mathrm{~m}$ away from the collection site. There are several cattle sheds but no horses are raised within a 4-kilometer radius from the collection site.

Collections were made between 16.00 and 18.00 hours during September-December 1988. Flies landing on or flying around the body surface of the human baits were captured by an aspiration tube or by an insect net, and held overnight in small plastic containers. The following day, flies were dissected in saline on a glass slide, and parity was determined by the presence of follicular relics (Detinova, 1962). Parous females were microscopically searched for filarial larvae. The larvae found were preserved in formalin-glycerol (Wharton, 1959) for morphometric observations.

About 170 blackflies collected in December were individually maintained with sucrose solution at $25^{\circ} \mathrm{C}$ for seven days, and dissected for the presence of third-stage filarial larvae. Generic diagnosis of third-stage larvae followed that of Bain and Chabaud (1986).

\section{RESULTS}

Four collections carried out from September to November 1988 yielded a total of eight blackfly species, but no Culicoides species was captured. The majority of blackfly species were Simulium bidentatum, followed by S. arakawae Matsumura, S. quinquestriatum (Shiraki) and S. aokii (Takahasi) (Table 1).

Natural infections with filarial larvae were found in $2.5 \%$ of 449 S. bidentatum collected (or $6.5 \%$ of the parous flies), and in $4.3 \%$ of 23 S. aokii captured (or $10 \%$ of the parous flies). Eight of 11 infected S. bidentatum had 1 to 4 first-stage larvae, two flies each harbored one second-stage larva, and one fly had two third-stage larvae probably just after the second moulting (Fig. 1). One infected S. aokii had one first-stage larva (Fig. 2). All the larvae were found in the thorax of the flies.

One of the two third-stage larvae (Fig. 1) recovered from September collection showed 
Table 1 Species composition, parity and natural infections of blackflies collected in Tabaru, one of the suburban residential areas, where a human case of zoonotic onchocerciasis occurred, in Oita, Japan

\begin{tabular}{|c|c|c|c|c|c|c|c|c|c|c|c|c|c|c|c|}
\hline \multirow[b]{3}{*}{$\begin{array}{l}\text { Simulium } \\
\text { spp. }\end{array}$} & \multicolumn{15}{|c|}{ Date of collection } \\
\hline & \multicolumn{3}{|c|}{ Sept. 23} & \multicolumn{3}{|c|}{ Oct. 6} & \multicolumn{3}{|c|}{ Oct. 13} & \multicolumn{3}{|c|}{ Nov. 17} & \multicolumn{3}{|c|}{ Total } \\
\hline & $\begin{array}{l}\text { No. } \\
\text { col. }\end{array}$ & $\begin{array}{l}\text { No. } \\
\text { par. }\end{array}$ & $\begin{array}{l}\text { No. } \\
\text { inf. }\end{array}$ & $\begin{array}{l}\text { No. } \\
\text { col. }\end{array}$ & $\begin{array}{l}\text { No. } \\
\text { par. }\end{array}$ & $\begin{array}{l}\text { No. } \\
\text { inf. }\end{array}$ & $\begin{array}{l}\text { No. } \\
\text { col. }\end{array}$ & $\begin{array}{l}\text { No. } \\
\text { par. }\end{array}$ & $\begin{array}{l}\text { No. } \\
\text { inf. }\end{array}$ & $\begin{array}{l}\text { No. } \\
\text { col. }\end{array}$ & $\begin{array}{l}\text { No. } \\
\text { par. }\end{array}$ & $\begin{array}{l}\text { No. } \\
\text { inf. }\end{array}$ & $\begin{array}{l}\text { No. } \\
\text { col. }\end{array}$ & $\begin{array}{l}\text { No. } \\
\text { par. }\end{array}$ & $\begin{array}{l}\text { No. } \\
\text { inf. }\end{array}$ \\
\hline aokii & 0 & - & - & 4 & 3 & 1 & 7 & 4 & 0 & 12 & 3 & 0 & 23 & 10 & 1 \\
\hline arakawae & 33 & 11 & 0 & 0 & - & - & 0 & - & - & 3 & 1 & 0 & 36 & 12 & 0 \\
\hline bidentatum & 88 & 30 & 4 & 43 & 9 & 0 & 174 & 69 & 4 & 144 & 62 & 3 & 449 & 170 & 11 \\
\hline japonicum & 0 & - & - & 0 & - & - & 1 & 0 & 0 & 1 & 0 & 0 & 2 & 0 & 0 \\
\hline nikkoense & 0 & - & - & 0 & - & - & 0 & - & - & 1 & 0 & 0 & 1 & 0 & 0 \\
\hline quinquestriatum & 0 & - & - & 1 & 0 & 0 & 2 & 0 & 0 & 30 & 10 & 0 & 33 & 10 & 0 \\
\hline rufibasis & 1 & 0 & 0 & 3 & 2 & 0 & 7 & 2 & 0 & 1 & 1 & 0 & 12 & 5 & 0 \\
\hline takahasii & 0 & - & - & 2 & 1 & 0 & 0 & - & - & 21 & 1 & 0 & 23 & 2 & 0 \\
\hline
\end{tabular}

the following measurements: total body length (BL) $743 \mu \mathrm{m}$, body width (BW) $26 \mu \mathrm{m}$, length of oesophagus (LE) $464 \mu \mathrm{m}$, length of tail (LT) $35 \mu \mathrm{m}$, width of tail (WT) $21 \mu \mathrm{m}$.

In dissections of flies maintained for seven days after collection, one of $144 \mathrm{~S}$. bidentatum examined had one third-stage larva (Fig. 3) in the thorax, but all of the 22 S. aokii were negative. The third-stage larva recovered (Fig. 3) showed following measurements: BL $1,280 \mu \mathrm{m}$, BW $25 \mu \mathrm{m}$, LE $620 \mu \mathrm{m}$, LT $45 \mu \mathrm{m}$, WT $20 \mu \mathrm{m}$. This larva, as well as two early third-stage larvae mentioned above, seemed to belong to the genus Onchocerca by possessing the very small, almost indiscernible caudal lappets.

It is generally impossible to identify the young third-stage larvae. However, the early third-stage larva found in September seemed to be distinct from the longer third-stage larva found in December because the ratio of $\mathrm{LE} / \mathrm{BL}$, as well as body length, was clearly different (i. e., 0.62 vs. 0.48 ). This conclusion is supported by our observations (unpublished data) that early third-stage larvae of the latter (long type Onchocerca) bear the short oesophagus (less than $1 / 2$ of body length) like mature third-stage larva, and measure over $850 \mu \mathrm{m}$ in body length.

It remained to be determined whether the filaria infecting $S$. aokii belongs to Onchocerca.

\section{Discussion}

Beaver et al. (1989) suggested that the human zoonotic onchocerciasis found in Oita was probably caused by $O$. gutturosa or $O$. cervicalis which have been commonly known in cattle and horses respectively around the world. Our result shows the least possibility that the causative worm was $O$. cervicalis, because its transmitter, Culicoides, was not captured during the daytime in the study area. This is also supported by the fact that horses, the definitive host of this parasite, were not raised around this area.

On the other hand, it is demonstrated that there were several anthropophilic blackfly species in the study area, and that S. bidentatum, the most dominant species, was naturally infected with larvae of Onchocerca. Examination of the third-stage larvae recovered shows 

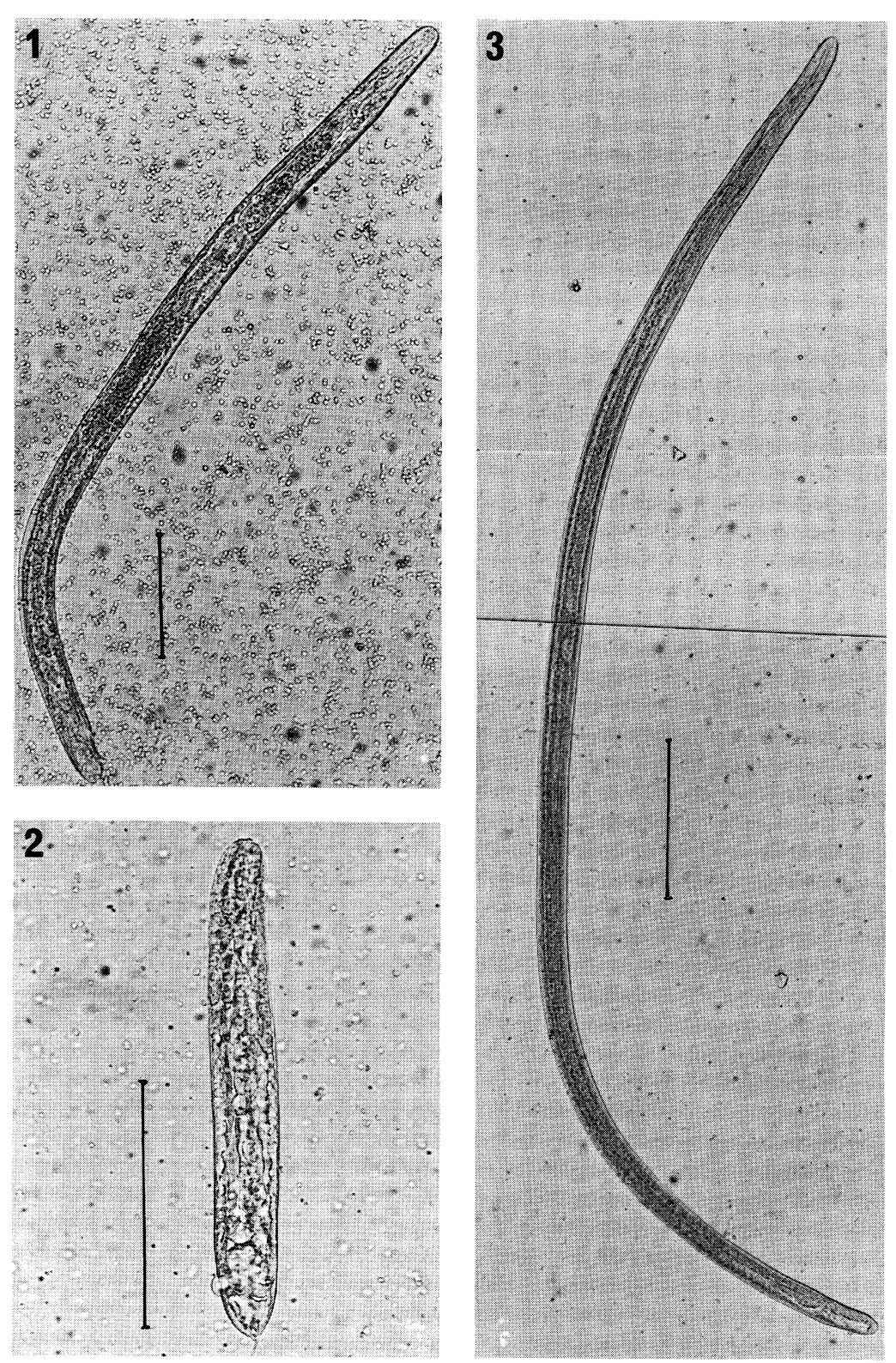

Figure 1 Early third-stage larva of Onchocerca sp. found in S. bidentatum dissected soon after collection.

Figure 2 First-stage larva of unidentified filaria found in S. aokii dissected soon after collection.

Figure 3 Third-stage larva of Onchocerca sp. found in S. bidentatum maintained for seven days after collection.

All scale bars indicate $100 \mu \mathrm{m}$ 
that $S$. bidentatum was infected with at least two Onchocerca species. One of these two fits in with the body length of third-stage larva of O. gutturosa given by Bain (1979), but more specimens of mature stage are needed to compare with the bovine parasite. The other one, though only one specimen is available, may belong to a new species because it has a very long body, as compared to those of other known Onchocerca species (Bain and Chabaud, 1986). At the present, it is thus difficult to conclude that the zoonotic Onchocerca acquired by a Japanese child was $O$. gutturosa, although it might be one of the two Onchocerca species found in S. bidentatum.

There were many cattle (both Holstein and Japanese Black) at several sheds set up in the farmland near the study area, and microfilariae of Onchocerca spp. were already found in blood-fed females of S. bidentatum, S. aokii and S. arakawae collected at one of five cowsheds examined. Further, three types of third-stage larvae of Onchocerca spp. were commonly discovered in the same blackfly species collected at the same cowshed (Takaoka and Bain, unpublished data). One of these three types of Onchocerca appears to be the same species as the longer third-stage larva found in this survey, and the remaining two types resemble thirdstage larvae of $O$. gutturosa and $O$. lienalis Stiles, 1908 respectively, although both of the latter two bovine filariae have been not yet recorded in Oita. Whether all these types of Onchocerca spp. recovered from Simulium spp. are parasites of cattle or of other animals should await future studies.

In summary, our findings indicate that there exists a situation, under which the zoonotic Onchocerca infection may be acquired by humans through biting of the local blackfly species, in the western suburbs of Oita.

\section{ACKNOWLEDGEMENTS}

We are grateful to Dr. I. Tada, Kumamoto University Medical School, for his valuable comments. Thanks are also due to Miss C. Aoki, and K. Ogata, Medical College of Oita for their assistance during this survey.

\section{REFERENCES}

1) Ali-Khan, Z. (1977): Tissue pathology and comparative microanatomy of Onchocerca from a resident of Ontario and other enzootic Onchocerca species from Canada and U.S.A., Ann. Trop. Med. Parasitol., 71, 469-482

2 ) Azarova, N.S., Miretskij, O.Y. and Sonin, M.D. (1965): The first discovered case of nematode parasitism in the USSR in a human being (genus Onchocerca Diesing, 1841), Med. Parazytol. (Moscow), 34, 156-158 (in Russian)

3 ) Bain, O. (1979): Transmission de l' Onchocerque bovine, Onchocerca gutturosa, par Culicoides, Ann. Parasitol., 54, 483-488

4 ) Bain, O. and Chabaud, A.G. (1986): Atlas des larves infestantes de filaires, Trop. Med. Parasit., 37, 301-340

5 ) Beaver, P.C., Horner, G.S. and Bilos, J.Z. (1974): Zoonotic onchocerciasis in a resident of Illinois and observations on the identification of Onchocerca species, Am. J. Trop. Med. Hyg., 23, 595-607

6 ) Beaver, P.C., Yoshimura, H., Takayasu, S., Hashimoto, H. and Little, M.D. (1989): Zoonotic Onchocerca in a Japanese child, Am. J. Trop. Med. Hyg., 40, 298-300 
7 ) Detinova, T.S. (1962): Age-grouping methods in Diptera of medical importance, Monograph Ser. W.H.O. no. 47 , pp. 217

8 ) Hashimoto, H., Murakami, I., Fujiwara, S., Takayasu, S., Takaoka, H., Uga, S., Akao, N., Kondo, K. and Yoshimura, H. (1990): A human case of zoonotic onchocerciasis in Japan, J. Dermatol., 17 (in press)

9 ) Sato, K., Hayashi, S. and Tanaka, H. (1954): Studies on the causative parasites of skin microfilariasis of cattle (Wahi Disease), Onchocerca gutturosa Neumann, 1910, and of equines (Kasen disease), Onchocerca cervicalis Railliet et Henry, 1910, Jpn. J. Parasitol., 2, 199-206 (in Japanese)

10) Siegenthaler, R. and Gubler, R. (1965): Paraatriculäres Nematodengranulom (einheimische Onchocerca), 95, 1102-1104

11) Suzuki, Y., Sugimura, M., Yagi, K., Ohbayashi, M. and Shoho, C. (1982): Onchocerciasis in wild Japanese serows, Capricornis crispus, Jpn. J. Vet. Sci., 44, 823-825

12) Wharton, R.H. (1959): A simple method of mounting and preserving filarial larvae, Bull. Wld. Hith Org., 20, 729-730

\title{
大分におけるキアシツメトゲブユの Onchocerca 幼虫自然感染 一特に動物寄生性 Onchocercaによる人への伝播に関して一
}

\author{
高岡 宏行 ${ }^{1}$ - 馬場 稔 ${ }^{1}$ Odile Bain $^{2}$
}

大分市の西部郊外において見いだされた, 動物寄生性 Onchocerca 線虫による人体例の伝播に 関して，患者の居住区において人囮法によって吸血ブユの採集を行い，フィラリア幼虫の感染の 有無を調べた。その結果，8種のブユが採集され，そのうちキアシツメトゲブユが優先種である ことが分かった。また本種ブユでは, 調べた449個体のうち11個体の雌に，フィラリア幼虫の感染 が見つかった。第 3 期幼虫の形態的観察により, Onchocerca 属に属する 2 種が含まれていること が分かった。これらの結果から, 動物寄生性 Onchocercaの人体への感染について考察を行った。

1 大分医科大学医動物学教室

2 Laboratoire Des Zoologie Vers., Museum National d'Histoire Naturelle, France 